\title{
KARAKTERISASI SENSOR ARUS DAN TEGANGAN UNTUK APLIKASI MAXIMUM POWER POINT TRACKER PADA SISTEM PENYIMPANAN ENERGI LISTRIK PANEL SURYA
}

\author{
Wisnu Satria Budi ${ }^{\text {a) }}$, Widyaningrum Indrasarib) ${ }^{\text {b) }}$ Riser Fahdiran ${ }^{\text {) }}$ \\ Prodi Fisika Fakultas Matematika dan IPA UNJ, Jalan Rawamangun Muka, Jakarta 13220, Indonesia \\ Email: a)wisnu94r11@gmaiil.com, ${ }^{\text {b) }}$ widyafisikaunj@gmail.com, ${ }^{c}$ riserfahdiran@unj.ac.id
}

\begin{abstract}
Abstrak
Penggunaan sel surya sebagai energi terbarukan dewasa ini semakin meluas. Berbagai upaya dilakukan agar panel surya mampu menghasilkan daya optimal. Salah satunya dengan menggunakan Maximum Power Point Tracker (MPPT). Hal ini bertujuan untuk mengontrol level tegangan keluaran panel surya. Maka dari itu pada penelitian ini dikarakterisasi dua buah sensor tegangan DC dan dua buah sensor arus INA219. Karakterisasi dilakukan menggunakan DC power supply dan enam variasi resistor. Hasil karakterisasi kedua sensor tegangan DC menunjukkan adanya tegangan offset masing-masing sebesar 0,0544 Volt dan 0,0564 Volt dengan kesalahan relatif pengukuran 0,19\% dan 0,20\%. Kemudian hasil karakterisasi kedua sensor arus INA219 menunjukkan adanya arus offset masing-masing sebesar $0,0291 \mathrm{~mA}$ dan $0,1495 \mathrm{~mA}$ dengan kesalahan relatif pengukuran $0,83 \%$ dan $2,96 \%$. Sensor ini akan digunakan untuk membaca tegangan dan arus pada aplikasi MPPT.
\end{abstract}

Kata-kata kunci: MPPT, sensor tegangan DC, INA219.

\begin{abstract}
Solar cell application as renewable energy today is increasingly widespread. Various attempts were made so that the solar panels can produce optimal power. One of them is by using Maximum Power Point Tracker (MPPT). MPPT is use for controlling the output voltage level of solar panel. Therefore, in this research characterized two DC voltage sensor and two INA219 current sensor. These characterizations are using a DC power supply and six variation of resistor. The result show that each of two DC voltage sensor have an offset voltage are 0,0544 Volt and 0,0564 Volt which have relative error of measurements are $0,19 \%$ and $0,20 \%$. Then, the result show to each of two INA219 current sensor have an offset current are $-0,0817 \mathrm{~mA}$ and $0,1222 \mathrm{~mA}$ which have relative error of measurement are $4,48 \%$ and $2,44 \%$. These sensors will use for sensing the voltage and current of MPPT application.
\end{abstract}

Keywords: MPPT, DC voltage sensor, INA219

\section{PENDAHULUAN}

Seiring dengan menipisnya ketersedian bahan bakar minyak dan batu bara di dunia membuat seluruh negara mencari solusi alternaitf. Energi terbarukan, seperti energi angin, energi panas bumi, 
dan energi matahari, dipilih sebagai alternatif sumber energi karena energi terbarukan merupakan energi yang bersih (clean energy) dan ketersediannya melimpah di alam. Pemanfaatan energi matahari untuk menghasilkan energi listrik dimulai pada tahun 1839 saat ditemukan efek photovoltaic dan kemas dalam sebuah teknologi sel surya [1].

Sel surya telah diciptakan pertama kali tahun 1954 yang disebut dengan sel surya generasi pertama. Sel surya generasi ini terbuat dari monocrystalline silicon [2]. Saat ini sel surya sudah dikembangkan dengan dilengkapi sistem tracker matahari dan menyematkan sistem sel surya hybrid. Pengembangan tersebut dimaksudkan agar meningkatkan produksi dari sel surya. Hasil prototipe yang telah dibuat seperti sel surya dengan sistem solar tracker dan sel surya dengan sistim hybrid [3]-[14]. Pengembangan selanjutnya dari sel surya yaitu meningkatkan efisensi pada sistem penyimpanan energi sel surya kedalam baterai. Salah satu metode yang digunakan yaitu Maximum Power Point Tracker (MPPT). MPPT berfungsi untuk mengontrol sel surya agar beroperasi secara efisien pada titik daya maksimumnya. Daya ini merupakan kalkulasi arus dan tegangan yang terbaca sensor [15]. Pengaplikasian MPPT memperlukan suatu komponen konverter DC-DC. Konverter ini berfungsi untuk mengatur level tegangan output agar sesuai dengan level tegangan pada baterai. Konverter DC-DC juga digunakan untuk mengisolasi noise, regulasi bus daya, dan lainnya [16].

Fokus penelitian pada paper ini adalah karakterisasi sensor arus dan sensor tegangan menggunakan mikrokontroller Arduino UNO untuk membaca keluaran sensor. Setelah sensor di karakterisasi, sensor ini akan di gunakan untuk membaca daya output panel surya dan daya output konverter pada aplikasi MPPT.

\section{METODOLOGI}

Proses karakterisasi pada penelitian ini menggunakan 2 buah sensor INA219, 2 buah sensor tegangan DC, multimeter digital Sanwa CD800a, resistor $(219 \Omega, 465 \Omega, 996 \Omega, 993 \Omega, 993 \Omega$, dan $4610 \Omega$ ), DC power supply dan system program menggunakan Arduino UNO. Sensor INA219 memiliki akurasi pembacaan nilai arus yang sangat baik dibandingkan dengan sensor arus AC712 karena terdapat internal multiplier di dalam board sensor. Sensor tegangan DC juga memliki akurasi pembacaan tegangan yang sangat baik dan telah banyak diaplikasikan pada penelitian secara global. Tahapan awal dalam penelitian ini yaitu menulis program untuk masing-masing sensor. Selanjutnya yaitu merangkai rangkaian seri untuk karakterisasi sensor arus INA219 dan rangkaian pararel untuk karakterisasi sensor tegangan DC. Selanjutnya melakukan uji coba pembacaan sensor. Selanjutnya melakukan proses karakterisasi, yaitu membandingkan nilai yang terbaca oleh sensor dengan nilai yang terbaca pada multimeter digital. Skema sistem dan proses karakterisasi ditunjukan pada GAMBAR 1. 

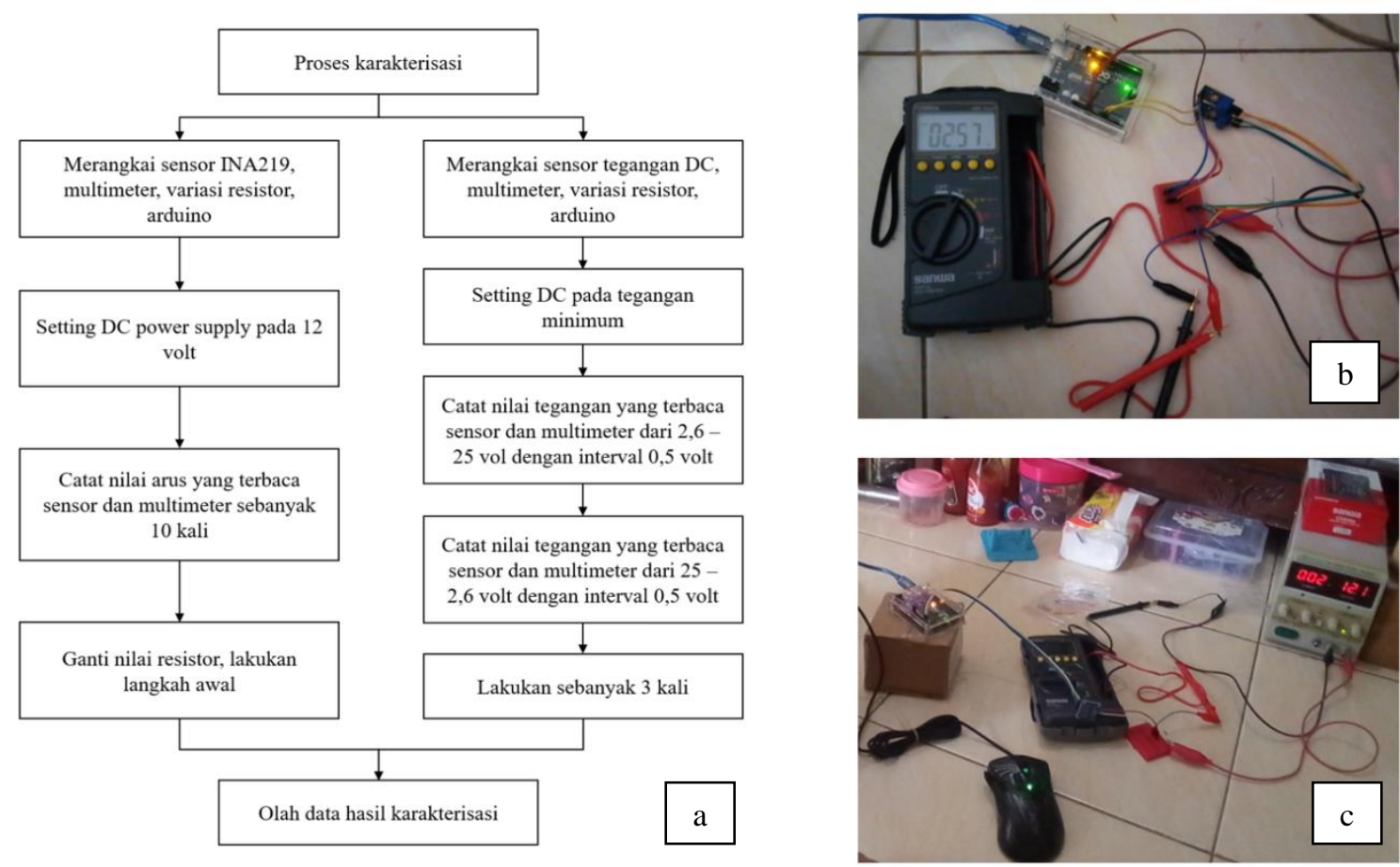

GAMBAR 1. (a) diagram penelitian (b) proses karakterisasi sensor INA219 (c) proses karakterisasi sensor tegangan DC.

\section{HASIL DAN PEMBAHASAN}

Karakterisasi sensor ini bertujuan untuk mengetahui karakteristik sensor seperti akurasi, fungsi transfer, nilai offset, kesalahan relatif dan rentang kerja sensor. Pada penelitian ini dilakukan karakterisasi 2 buah sensor INA219 dan 2 buah sensor tegangan DC. Masing masing akan diberi label A dan B.

\section{Karakterisasi Sensor INA219}

Sensor INA219 merupakan sebuah sensor modul yang digunakan untuk mengukur arus dan teganan DC dengan interface I2C. Sensor ini berkerja dengan daya masukan 3-5,5 VDC. Cara kerja sensor ini yaitu mengukur arus di dalam rangkaian seri yang masuk melalui block terminal. Kemudian pin pada sensor ini di hubungkan dengan dengan Arduino. Karakterisasi sensor ini dilakukan dengan menggunakan enam variasi resitor, yaitu $219 \Omega, 465 \Omega, 996 \Omega, 1989 \Omega, 2982 \Omega$, dan $4610 \Omega$. Pembacaan nilai keluaran sensor dan multimeter dilakukan sebanyak 10 kali pada setiap variasi sensor. Hasil karakterisasi sensor INA219 A dan INA219 B ditunjukkan pada GAMBAR 2.

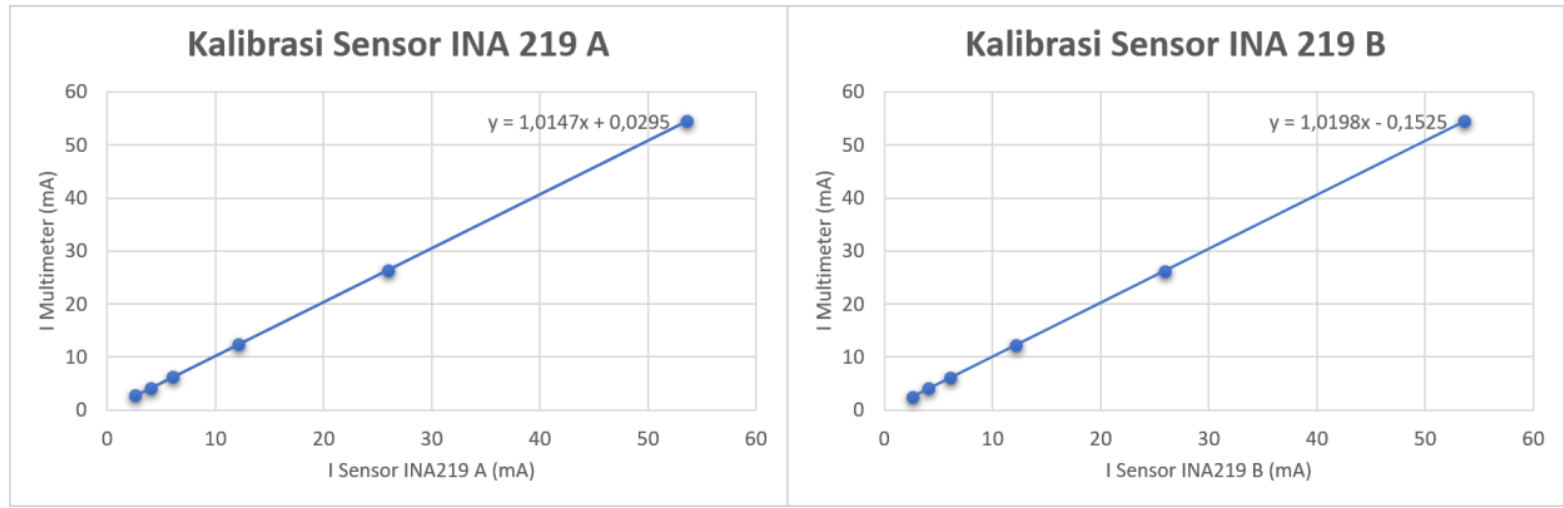

GAMBAR 2. Karakterisasi sensor INA219 A dan INA219 B. 
Berdasarkan grafik diatas kita mengetahui persamaan regresi dari sensor dengan multimeter yaitu nilai keluaran kedua sensor berbentuk linear. Persamaan tersebut kemudian kita invers aga menjadi fungsi transfer dari sensor. Fungsi transfer untun sensor INA219 A dan INA219 B sebagai berikut :

$$
\begin{aligned}
& I_{A}=0,9855 I_{S}-0,0291 \\
& I_{B}=0,9806 I_{S}+0,1495
\end{aligned}
$$

Dimana $I_{S}$ adalah arus yang terbaca oleh sensor $(\mathrm{mA}), \mathrm{I}_{\mathrm{A}}$ dan $\mathrm{I}_{\mathrm{B}}$ adalah arus sebenarnya yang terukur (mA). Kemudian sensor juga memiliki arus offset yaitu -0,0291 mA untuk sensor INA219 A dan 0,1495 mA untuk sensor INA219 B. Hasil pengolahan data menunjukkan bahwa sensor INA219 A dan INA219 B memliki kesalahan relatif sebesar 0,83\% dan 2,96\%. Nilai kesalahan relatif pada sensor ini lebih baik dibandingkan dengan kesalahan relatif hasil karakterisasi yang terdapat pada referensi [10],yaitu 9,6\% dengan metode yang sama.

\section{Karakterisasi Sensor Tegangan DC}

Sensor tegangan DC merupakan sebuah sensor tegangan yang dapat mengukur tegangan dari 0 25 VDC. Sensor ini bekerja dengan daya masukan Vcc 5 volt. Cara kerja sensor ini yaitu mengukur arus pada rangkaian pararel melalui block terminal. Kemudian pin pada sensor ini dibuhungkan dengan Arduino. Karakterisasi sensor ini dilakukan dilakukan dengan menaikkan dan menurunkan tegangan sumber dari 2,6 - 25 Volt dan sebaliknya dengan interval 0,5 Volt. Pembacaan nilai keluaran sensor dan multimeter dilakukan pada setiap interval. Karakterisasi ini dilakukan sebanyak tiga kali pengulangan menaikkan dan menurunkan tegangan. Hasil karakterisasi sensor tegangan DC A dan sensor tegangan DC B ditunjukkan pada GAMBAR 3.
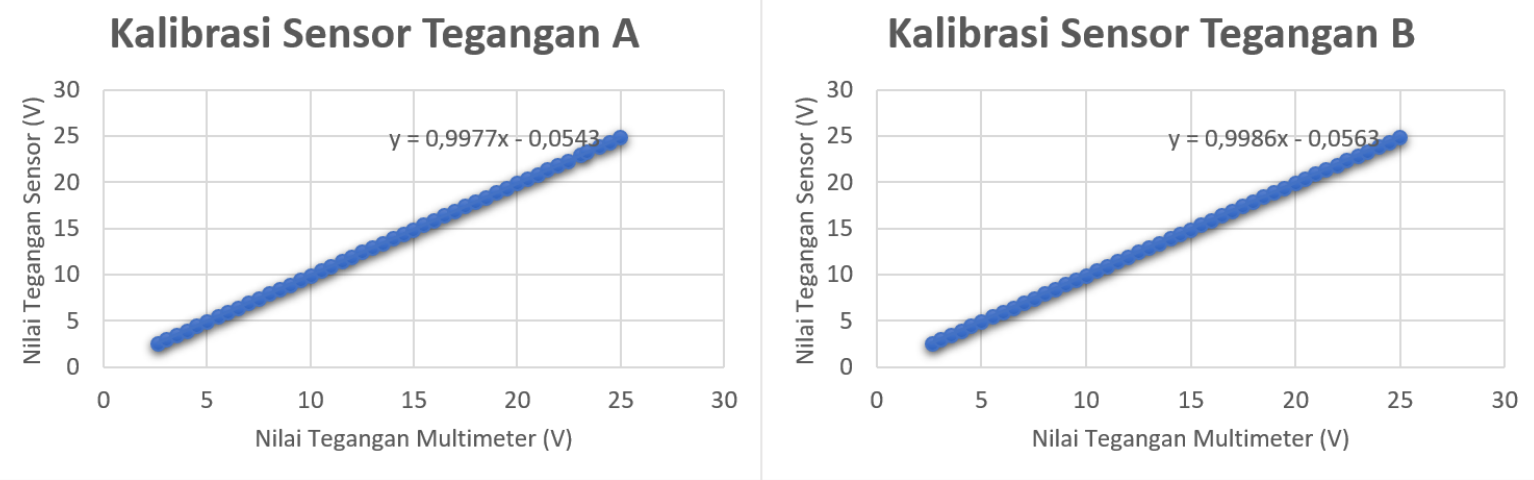

GAMBAR 3. Karakterisasi sensor INA219 A dan INA219 B.

Berdasarkan grafik diatas kita mengetahui persamaan regresi dari sensor dengan multimeter yaitu nilai keluaran kedua sensor berbentuk linear. Persamaan tersebut kemudian kita invers aga menjadi fungsi transfer dari sensor. Fungsi transfer untun sensor tegangan DC A dan sensor tegangan DC B sebagai berikut :

$$
\begin{aligned}
& \mathrm{V}_{\mathrm{A}}=1,0023 \mathrm{~V}_{\mathrm{S}}+0,0544 \\
& \mathrm{~V}_{\mathrm{B}}=1,0014 \mathrm{~V}_{\mathrm{S}}+0,0564
\end{aligned}
$$

Dimana $\mathrm{V}_{\mathrm{S}}$ adalah tegangan yang terbaca oleh sensor $(\mathrm{V}), \mathrm{V}_{\mathrm{A}}$ dan $\mathrm{V}_{\mathrm{B}}$ adalah tegangan sebenarnya yang terukur (V). Kemudian sensor juga memiliki tegangan offset yaitu 0,0544 V untuk sensor tegangan DC A dan $0,0564 \mathrm{~V}$ untuk sensor tegangan DC B. Hasil pengolahan data menunjukkan bahwa sensor tegangan DC A dan sensor tegangan DC B memliki kesalahan relatif sebesar $0,19 \%$ dan $0,20 \%$. Nilai kesalahan relatif pada sensor ini lebih baik dibandingkan dengan kesalahan relatif hasil karakterisasi yang terdapat pada referensi [10],yaitu 0,77\% dengan metode yang sama. 


\section{SIMPULAN}

Karakterisasi 2 buah sensor INA219 dan 2 buah sensor tegangan DC telah dilakukan. Penggunaan sensor INA219 sebagai alat ukur arus cukup akurat karena sensor INA219 memiliki kesalahan relatif pengukuran yaitu $0,83 \%$ dan $2,96 \%$. Kemudian penggunaan sensor tegangan DC sebagai alat ukur tegangan sangat akurat karena sensor tegangan DC memiliki kesalahan relatif pengukuran yaitu $0,19 \%$ dan $20 \%$. Kedua jenis sensor dapat digunakan untuk mengukur daya dalam aplikasi MPPT.

\section{REFERENSI}

[1] K. Ranabhat et al., "An introduction to solar cell technology," J. Appl. Eng. Sci, vol. 14, no. 4, pp. 481-491, 2016, doi: 10.5937/jaes14-10879.

[2] T. Pavlovic, "The Sun and Photovoltaic Technologies," 2020.

[3] W. Indrasari et al., "Active Solar Tracker Based on the Horizon Coordinate System," J. Phys. Conf. Ser, vol. 1120, no. 1, 2018, doi: 10.1088/1742-6596/1120/1/012102.

[4] F. M. Hoffmann et al., "Monthly profile analysis based on a two-axis solar tracker proposal for photovoltaic panels," Renew. Energy, vol. 115, pp. 750-759, 2018, doi: 10.1016/j.renene.2017.08.079.

[5] G. Li et al., "A review of solar photovoltaic-thermoelectric hybrid system for electricity generation," Energy, vol. 158, pp. 41-58, 2018, doi: 10.1016/j.energy.2018.06.021.

[6] W. Indrasari, Habiburosid and R. Fahdiran, "Characterization of hybrid solar panel prototype using PV-TEG module," 8Th Natl. Phys. Semin, vol. 2169, no. 1, p. 050005, 2019, doi: $10.1063 / 1.5132678$.

[7] E. Parikesit, D. Purwadianto and F. A. R. Sambada, "Pelacak Matahari Dua Sumbu Menggunakan LDR untuk Meningkatkan Absorbsi Matahari," Media Tek. Univ. Sanata Dharma, vol. 12, no. 2, pp. 80-90, 2017.

[8] S. Ozcelik, H. Prakash and R. Challoo, "Two-axis solar tracker analysis and control for maximum power generation," Procedia Comput. Sci, vol. 6, pp. 457-462, 2011, doi: 10.1016/j.procs.2011.08.085

[9] R. Eke and A. Senturk, "Performance comparison of a double-axis sun tracking versus fixed PV system," Sol. Energy, vol. 86, no. 9, pp. 2665-2672, 2012, doi: 10.1016/j.solener.2012.06.006.

[10] W. Indrasari et al., "Development of static solar panel equipped by an active reflector based on LDR sensors," J. Phys. Conf. Ser, vol. 1280, no. 2, 2019, doi: 10.1088/17426596/1280/2/022071.

[11] A. Yani, "Pengaruh Penambahan Alat Pencari Arah Sinar Daya Output Solar Cell," Turbo J. Progr. Stud. Tek. Mesin, vol. 5, no. 2, pp. 82-87, 2016, [Online]. Available: http://ojs.ummetro.ac.id/index.php/turbo.

[12] E. A. Setiawan and K. Dewi, "Impact of two types flat reflector materials on solar panel characteristics," Int. J. Technol, vol. 4, no. 2, pp. 188-199, 2013, doi: 10.14716/ijtech.v4i2.108.

[13] C. K. Yang et al., "Open-loop altitude-azimuth concentrated solar tracking system for solarthermal applications," Sol. Energy, vol. 147, pp. 52-60, 2017, doi: 10.1016/j.solener.2017.03.014.

[14] D. L. Pangestuningtyas, Hermawan, and Karnoto, "Analisis Pengaruh Sudut Kemiringan Panel Surya Terhadap Radiasi Matahari Yang Diterima Oleh Panel Surya Tipe Larik Tetap," Transient, vol. 2, pp. 0-7, 2013. 
[15] J. P. Ram, T. S. Babu and N. Rajasekar, "A comprehensive review on solar PV maximum power point tracking techniques," Renew. Sustain. Energy Rev, vol. 67, pp. 826-847, 2017, doi: 10.1016/j.rser.2016.09.076.

[16] D. Choudhary and A. R. Saxena, "DC-DC Buck-Converter for MPPT of PV System," Int. J. Emerg. Technol. Adv. Eng, vol. 4, no. 7, p. 9, 2014. 